\title{
Pharmacogenetics and personalized treatment of type 2 diabetes
}

\author{
Sabina Semiz ${ }^{12^{*}}$, Tanja Dujic ${ }^{1}$, Adlija Causevic ${ }^{1}$ \\ 1'Department of Biochemistry and Clinical Analysis, Faculty of Pharmacy, University of Sarajevo, Sarajevo, Bosnia and Herzegovina \\ ${ }^{2}$ Faculty of Engineering and Natural Sciences, International University of Sarajevo, Sarajevo, Bosnia and Herzegovina \\ ${ }^{*}$ Corresponding author: sabinasemiz@hotmail.com
}

\begin{abstract}
Type 2 diabetes mellitus (T2DM) is a worldwide epidemic with considerable health and economic consequences. T2DM patients are often treated with more than one drug, including oral antidiabetic drugs (OAD) and drugs used to treat diabetic complications, such as dyslipidemia and hypertension. If genetic testing could be employed to predict treatment outcome, appropriate measures could be taken to treat T2DM more efficiently. Here we provide a review of pharmacogenetic studies focused on OAD and a role of common drug-metabolizing enzymes (DME) and drug-transporters (DT) variants in therapy outcomes. For example, genetic variations of several membrane transporters, including SLC22A1/2 and SLC47A1/2 genes, are implicated in the highly variable glycemic response to metformin, a first-line drug used to treat newly diagnosed T2DM. Furthermore, cytochrome P450 (CYP) enzymes are implicated in variation of sulphonylurea and meglitinide metabolism. Additional variants related to drug target and diabetes risk genes have been also linked to interindividual differences in the efficacy and toxicity of OAD. Thus, in addition to promoting safe and cost-effective individualized diabetes treatment, pharmacogenomics has a great potential to complement current efforts to optimize treatment of diabetes and lead towards its effective and personalized care.
\end{abstract}

Key words: type 2 diabetes mellitus; pharmacogenomics; pharmacogenetics; oral antidiabetic drugs; personalized medicine

\section{Introduction}

It has been estimated that around 285 million people suffer from type 2 diabetes mellitus (T2DM) with projected rise to 438 million in the next 20 years (1). Current therapies for T2DM include lifestyle modification and use of oral antidiabetic drugs (OAD). Several OAD classes are currently available to treat T2DM patients, with sulphonylureas (SU), biguanides, thiazolidinediones (TZDs), and meglitnides being the most frequently used. Effects of these drugs depend on the extent of drug absorption from the gut lumen, uptake and metabolism of the drug in the liver, the extent of its transport back into the systemic circulation for extrahepatic effects, and for drugs with substantial renal secretory clearance (e.g., metformin) on active renal tubular secretion into the urine. Drugmetabolizing enzymes (DME) and drug transport- ers (DT) have a crucial role in the fate of drugs in human body. Information regarding the incidence of cytochrome P450 (CYP) gene polymorphisms is increasing (2-4), although the level of detail such as in the case of other DME, including UDP-glucuronosyltransferases and $\mathrm{N}$-acetyltransferases, is not as extensive. In addition, recent studies identified genetic variations of DT associated with the altered treatment outcomes $(5,6)$ and revealed an important role of the transporter-mediated OAD uptake in their disposition and effects (4).

Furthermore, recent data showed that epigenetic changes in response to environmental stimuli may play an important role in the diabetes development (7). In addition to the role of DNA methylation and histone modifications, recent studies also indicated that microRNAs (miRNAs), a class of 
small, single-stranded non-protein coding gene products that post-transcriptionally suppress mRNA target expression, could serve as a new generation of biomarkers for diabetes. Strikingly, a recent analysis of the specific miRNAs provided sufficient data to diagnose and predict the T2DM development in normoglycemic patients (8). Thus, characterization of the miRNAs pattern together with the analysis of specific pharmacogenetic variants could facilitate the design of a therapy tailored to the individual patient, contributing to the current efforts in the personalized medicine $(9,10)$. Here we aim to summarize the pharmacogenomics data related to the T2DM therapy, particularly the associations of SU, TZDs, biguanides, and meglitinides treatment outcomes with polymorphisms of DME, DT, drug target and diabetes risk genes that might lead to the promotion of personalized T2DM treatment.

\section{Sulphonylureas}

In addition to insulin resistance (IR), insufficient pancreatic $\beta$-cell function plays an important role in the pathogenesis of T2DM. The insufficient production and secretion of insulin can be increased by secretagogue drugs, like SU that bind to sulphonylurea receptor (SUR) leading to the cell depolarization and stimulation of insulin release. Potassium inwardly rectifier 6.2 subunit (Kir6.2) of pancreatic islet ATP-sensitive $\mathrm{K}+$ (KATP) channels are heterooctamers assembled from Kir6.2 and the sulphonylurea receptor 1 (SUR1), encoded by the KCNJ11 and ABCC8 gene, respectively. This channel is essential for glucose-stimulated insulin secretion from pancreatic $\beta$-cells, modulates glucose uptake into skeletal muscle, glucose production and release from the liver (11). Physiologically, decreased plasma glucose levels lead to lower metabolic rate which opens KATP channels, suppressing electrical activity and insulin release. In contrast, KATP channels close when metabolism increases, ATP rises and MgADP falls, leading to membrane depolarization, opening of voltage-gated $\mathrm{Ca} 2+$ channels, Ca2+ influx, and insulin secretion.

In recent years single nucleotide polymorphisms (SNPs) of the genes encoding KATP channel have been related to the efficacy of secretagogue drugs (Table 1). Loss-of-function (LOF) mutations of these genes are the most common cause of congenital hyperinsulinism, with over 150 mutations characterized in SUR1 ( $A B C C 8)$ and 24 in Kir6.2 (KCNJ11) (12). On the other hand, gain-of-function (GOF) mutations in Kir6.2 or SUR1 cause neonatal diabetes (ND). A similar number of over 40 different ND mutations have been characterized in Kir6.2 and in SUR1 (12). All Kir6.2 mutations cause dominant ND by reducing the ability of ATP to block KATP channel (13), hyperpolarizing the $\beta$-cells, and preventing insulin secretion. Thus, the mutated KATP channel does not close in response to increased ATP concentrations. However, it could be closed when SU bind to SUR1 by an ATP-independent route. The discovery of the causal role of KATP channels has enabled ND patients to switch from insulin to SU therapy that significantly improved glycemic control and reduced the risk of diabetic complications $(14,15)$.

A common Glu23Lys polymorphism (also known as E23K) in KCNJ11 (potassium inwardly-rectifying channel, subfamily J, member 11) gene encoding Kir6.2, is associated with T2DM development $(16,17)$, as well as an increased risk of SU therapeutic failure (18). The functional effects of the E23K variant on insulin secretion and insulin sensitivity in humans are controversial, although recent larger studies demonstrate a significantly reduced insulin secretion, lower insulin levels, and improved insulin sensitivity (19), consistent with enhanced KATP activity in pancreatic $\beta$-cells. Furthermore, a recent study found that the carriers of the KCNJ11 K-allele had better therapeutic response to gliclazide (20). KCNJ11 variations have been also associated with altered response to glibenclamide therapy and misdiagnosis of Type 1 diabetes (14). Importantly, recent evidence demonstrated that patients with KCNJ11 mutations could be treated more efficiently with SU than with insulin $(14,21,22)$.

The $A B C C 8$ gene encodes the SUR1 subunit which regulates KATP channel activity. $A B C C 8$ mutations are genetically more heterogeneous, with homozygous, heterozygous and compound hetero- 
TABLE 1. Summary of the gene polymorphisms involved in the pharmacogenetics of sulphonylureas.

\begin{tabular}{|c|c|c|c|}
\hline SNP & Study population & Associated response phenotype & Reference \\
\hline \multicolumn{4}{|l|}{ KCNJ11 } \\
\hline \multirow[t]{2}{*}{$\begin{array}{l}\text { E23K (Glu23Lys) } \\
\quad(\text { rs5219) }\end{array}$} & $\begin{array}{l}\text { T2DM patients }(\mathrm{N}=525) \text { with } \\
\text { secondary SU failure. }\end{array}$ & $\begin{array}{l}\text { Carriers of the K allele showed a tendency toward shorter } \\
\text { duration of therapy before failure as compared with EE } \\
\text { homozygotes; pancreatic islets from K allele carriers showed } \\
\text { a significantly lower glibenclamide-stimulated insulin release. }\end{array}$ & $\begin{array}{l}\text { Sesti et al, } \\
2006(18)\end{array}$ \\
\hline & $\begin{array}{l}\text { Patients with T2DM }(\mathrm{N}=101) \\
\text { treated with gliclazide for } 6 \text { months. }\end{array}$ & $\begin{array}{l}\text { K-allele carriers had significantly higher decrease in } \mathrm{HbA1c} \\
\text { compared with EE homozygotes. }\end{array}$ & $\begin{array}{l}\text { Javorsky et al, } \\
2012(20)\end{array}$ \\
\hline $\begin{array}{l}3 p+215 G>A \\
\quad(r s 5210)\end{array}$ & $\begin{array}{l}\text { Patients with T2DM ( } \mathrm{N}=1.268), 8 \\
\text { weeks of gliclazide therapy. }\end{array}$ & Significantly associated with decrease in FPG. & $\begin{array}{l}\text { Feng et al, } \\
2008(25)\end{array}$ \\
\hline \multicolumn{4}{|l|}{$A B C C 8$} \\
\hline $\begin{array}{l}\text { Ser1369Ala } \\
\text { (rs757110) }\end{array}$ & $\begin{array}{l}\text { Patients with T2DM }(\mathrm{N}=1.268), 8 \\
\text { weeks of gliclazide therapy. }\end{array}$ & Associated with significant decrease in FPG. & $\begin{array}{l}\text { Feng et al, } \\
2008(25)\end{array}$ \\
\hline $\begin{array}{l}\text { exon } 16-3 C>T \\
(r s 1799854)\end{array}$ & $\begin{array}{l}\text { Patients with T2DM }(\mathrm{N}=228) \text { on SU } \\
\text { therapy. }\end{array}$ & $\begin{array}{l}\text { Carriers of wild-type CC genotype had significantly lower } \\
\text { HbA1c compared to the patients with TT genotype. }\end{array}$ & $\begin{array}{l}\text { Nikolac et al, } \\
\text { 2009. (28) }\end{array}$ \\
\hline \multirow[t]{2}{*}{$\begin{array}{l}\text { Arg1273Arg } \\
\text { (rs1799859) }\end{array}$} & $\begin{array}{c}\text { Patients with T2DM }(\mathrm{N}=228) \text { on SU } \\
\text { therapy. }\end{array}$ & $\begin{array}{l}\text { Patients with wild-type GG genotype had significantly } \\
\text { higher HbA1c levels compared to the patients with AA } \\
\text { genotype. }\end{array}$ & $\begin{array}{l}\text { Nikolac et al, } \\
2009 \text { (28) }\end{array}$ \\
\hline & $\begin{array}{l}\text { Patients with T2DM }(\mathrm{N}=251) \text { on SU } \\
\text { therapy. }\end{array}$ & $\begin{array}{c}\text { Patients with GG genotype had significantly higher } \\
\text { triglyceride levels compared to the patients with AA } \\
\text { genotype. }\end{array}$ & $\begin{array}{l}\text { Nikolac et al, } \\
2012 \text { (29) }\end{array}$ \\
\hline
\end{tabular}

\section{KCNQ1}

rs163184 T>G T2DM patients $(\mathrm{N}=87)$ who failed to achieve glycemic control on metformin therapy, treated 6 months with SU.
Carriers of the T-allele (TT+TG) achieved significantly lower FPG levels compared to the patients with the risk GG genotype.
Schroner et al, 2011 (34)

\section{TCF7L2}

rs7903146 C>T T2DM patients $(\mathrm{N}=87)$ 6-month sulphonylurea in addition to metformin.

T2DM patients $(\mathrm{N}=189)$, 6-month SU treatment.

rs12255372 G>T Population-based GoDARTS study: rs7903146 C>T T2DM patients, incident SU users $(\mathrm{N}=901)$.
Significantly higher reduction in HbA1c and FPG in patients with CC genotype compared to the CT+TT genotype.

T allele was significantly more frequent in patients who failed to respond to SU than in the control subjects.

2-fold greater likelihood of SU failure (not to achieve target $\mathrm{HbA} 1 \mathrm{c}<7 \%(53 \mathrm{mmol} / \mathrm{mol}))$ in the $12 \%$ of the TT homozygotes at rs1225372 than in the GG group.
Schroner et al, 2011 (39)

Holstein et al, 2011 (41)

Pearson et al, 2007 (40)

\section{CYP2C9}

*3 (Ile359Leu) Healthy volunteers $(\mathrm{N}=21)$, a single (rs1057910) oral dose of glyburide.

In *3/*3 homozygotes total drug clearance was less than half, while insulin secretion was higher as compared to the wild-type ${ }^{*} 1 /{ }^{*} 1$ genotype.

Healthy volunteers $(\mathrm{N}=29)$.

A population-based cohort Rotterdam Study ( $\mathrm{N}=7.983)$.

*2 (Arg144Cys) Population-based GoDARTS study: (rs1799853) T2D patients, incident users of SU

*3 (Ile359Leu) (rs1057910)

$$
(\mathrm{N}=1.073) \text {. }
$$

In *3 allele heterozygotes higher the median total AUC of glyburide and glimepiride, compared to subjects with the *1/*1 genotype.

Carriers of $* 3$ allele required lower doses of tolbutamide to regulate glucose levels as compared to the ${ }^{*} 1 /{ }^{*} 1$ genotype.

More likely to achieve a treatment $\mathrm{HbA} 1 \mathrm{c}<7 \%$ (53 mmol/ $\mathrm{mol}$ ) than patients with the wild-type genotype.
Kirchheiner et al, 2002 (48)

Niemi et al, 2002 (49)

Becker et al, 2008 (42)

Zhou et al, 2010 (51)

FPG - fasting plasma glucose; AUC - area under the curve. 
zygous mutations being described (23). Heterozygous activating mutations in the $A B C C 8$ gene have been characterized as a cause of permanent and transient ND that may present as T2DM (24). Interestingly, a common Ser1369Ala SNP of ABCC8 influenced antidiabetic efficacy of SU in Chinese (25), but not in German population (26). In addition, this same Ser1369Ala variant of $A B C C 8$ appeared not to be associated with the risk for severe SU-induced hypoglycemia in German (26) and Japanese (27) T2DM patients. Additional polymorphisms of $A B C C 8$ gene, including SNP in exon 16 $(-3 C / T)$ and exon 31 (Arg1273Arg) have been also reported to be associated with the SU efficacy in European Caucasians (28-30).

Importantly, two common ATP-sensitive potassium (KATP) channel variants, E23K and S1369A, of the KCNJ11 and $A B C C 8$ genes respectively, are in strong linkage disequilibrium (LD) and form a haplotype that appears to be associated with an increased T2DM risk (31). A recent analysis of structure-activity relationships in KATP channels containing either the E23/S1369 non-risk or K23/A1369 risk haplotypes, demonstrated that KATP channels containing the K23/A1369 risk haplotype were significantly less sensitive to inhibition by tolbutamide, chlorpropamide, and glimepiride (32). Glibenclamide and glipizide demonstrated similar inhibitory effects on KATP channels in patients with either haplotype. Based on these data, the authors suggested that it would be possible to design novel OAD with an increased efficacy in patients homozygous for these common KATP channel haplotypes.

Patients with deficient hepatic nuclear factor-1-alpha (HNF1-alpha), a transcription factor vital for correct $\beta$-cell development and function, have progressive $\beta$-cell deterioration and are more sensitive to SU than matched T2DM patients (33). Furthermore, a recent study has suggested that the magnitude of fasting plasma glucose (FPG) levels reduction after 6-month SU treatment in addition to metformin in T2DM patients was related to the rs163184 (T>G) SNP in KCNQ1 gene (34). KCNQ1 encodes a voltage-gated potassium channel expressed in the heart, stomach, small and large intestine, kidney, and pancreas. However, its role in insulin secretion by pancreatic $\beta$-cells is not completely understood. Importantly, the FPG response to $\mathrm{SU}$ was significantly lower in carriers of the risk GG genotype of rs163184 variation in KCNQ1 (34). In addition, the $\operatorname{Arg}(972)$ variant of IRS-1 gene encoding the insulin receptor substrate (IRS)-1 that is an important component of the insulin signaling cascade, was also associated with an increased risk for secondary SU failure (35).

The most promising gene variants affecting the SU response are those involved in drug pharmacodynamics, such as the transcription factor 7-like 2 (TCF7L2) that encodes a transcription factor (Tcf-4), involved in the regulation of cellular proliferation and differentiation (36). TCF7L2 gene has the strongest association with $\mathrm{T} 2 \mathrm{DM}$ reported to date $(37,38)$. A recent study demonstrated that the degree of reduction in HbA1c and FPG levels following a combined $\mathrm{SU}$ and metformin treatment was related to TCF7L2 rs7903146 (C>T) SNP (39). Interestingly, individuals with the T2DM-associated homozygous TT genotype were less likely to respond to SU therapy (39-41).

Sulphonylureas are mainly metabolized by the enzyme cytochrome P450 (CYP) isoform CYP2C9. A recent population-based Rotterdam study showed that polymorphisms in CYP2C9 gene affected the patient sensitivity to SU (42). The carriers of CYP2C9*3 (Ile359Leu) polymorphism appeared to be protected against development of T2DM (43), while CYP2C9*2 (Arg144Cys) polymorphism was not associated with diabetes susceptibility (44). Although these two allelic variants, CYP2C9*2 and CYP2C9*3, have been associated with elevated SU serum levels, the tolbutamide dose was lower in CYP2C9*3 allele carriers as compared to patients with the wild-type CYP2C9 genotype, while similar effect was not observed for the CYP2C9*2 genotype (42). Furthermore, CYP2C9*3 increased the risk of hypoglycemia in T2DM patients treated with SU $(43,45)$ and multiple studies indicated that the CYP2C9*3 allele was associated with decreased SU clearance $(46,47)$. Homozygous carriers of the CYP2C ${ }^{*} 3{ }^{*} 3$ genotypes had reduced clearance of glyburide and increased insulin secretion following glyburide administration $(48,49)$. Furthermore, diabetic patients with a CYP2C9*3 variant required 
lower doses of tolbutamide for glucose control than patients with the wild-type genotype (42). Recently, Swen et al. (50) demonstrated no significant effects of the CYP2C9*2 and CYP2C9*3 alleles on prescribed dose in incident SU users. However, a large population-based GoDARTS (Genetics of Diabetes Audit and Research in Tayside Scotland) study performed in 1,073 incident SU users demonstrated that patients with two copies of the ${ }^{*} 2$ or *3 alleles were three times more likely to achieve treatment target of $\mathrm{HbA1C}$ levels under $7 \%(53$ $\mathrm{mmol} / \mathrm{mol}$ ) than patients with two wild-type CYP2C9*1 alleles (51).

\section{Thiazolidinediones}

Thiazolidinediones, also known as glitazones, act by activating their molecular target, PPARs (peroxisome proliferator-activated receptors). TZDs bind with greatest specificity for PPAR $\gamma$, a nuclear transcription factor expressed diffusely in humans, including adipocytes, to promote adipogenesis and fatty acid uptake. By reducing circulating fatty acid concentrations and lipid availability in liver and muscle, these drugs improve the patients' sensitivity to insulin and reduce hyperglycemia. In addition, TZDs have a multitude of other therapeutic effects including anti-inflammatory effects and amelioration of hypertension, microalbuminuria and hepatic steatosis (52).

Rosiglitazone and pioglitazone are TZDs that have been shown to improve glycemic control and may act to slow the progression of $\beta$-cell failure. However, recent studies demonstrated that use of rosiglitazone could cause serious side effects, including an increased risk of myocardial infarction and death from cardiovascular causes as compared to pioglitazone $(53,54)$. Due to these serious side effects, the European Medicines Agency (EMA) has recommended the suspension of the marketing authorizations for the rosiglitazone, while US Food and Drug Administration (FDA) has decided that rosiglitazone can remain available, but only under a very stringent restricted access program. Thus, the only TZD that is still available on market is pioglitazone, which appears to have more favorable effects on cardiovascular system in T2DM patients as compared to rosiglitazone $(55,56)$. The mechanism of the antidiabetic action of pioglitazone involves activation of PPARy, while its direct antioxidant action may also contribute to its effect on IR (57). However, the treatment with pioglitazone for more than one year may be associated with an increased risk of bladder cancer (58-60).

Recently, as shown in Table 2, several gene variants have been also associated with the TZDs therapy outcomes (61). Adipokinins, including adiponectin, leptin, resistin, peroxisome proliferator-activated receptor $\gamma$ (PPAR $\gamma$ ) and tumor necrosis factor (TNF)- $a$, are of a particular interest due to their important role in IR. Loss-of-function mutations in PPARy are associated with severe IR and diabetes mellitus (62). Variants in PPARG or ADIPOQ (adiponectin) have been variably associated with TZDs response. Strikingly, rosiglitazone was significantly more effective in diabetic patients with Pro12Ala polymorphism of PPARG, who consequently had a significantly greater decrease in FPG and HbA1c levels than carriers of the wild-type genotype (63). A recent study reported that Thr394Thr and Gly482Ser SNPs of the peroxisome proliferator activated receptor- $\gamma$ coactivator-1a (PGC-1a), which is a transcriptional coactivator of PPAR $y$, were also associated with rosiglitazone efficacy in Chinese T2DM patients (64). In addition, a pilot study suggested that the G/G genotype of resistin SNP-420 may be an independent predictor of the reduction of FPG and HOMA-IR (Homeostasis Model of Assessment-Insulin Resistance) by pioglitazone (65). Furthermore, recent studies demonstrated that the genetic variations of $-11377 \mathrm{C} / \mathrm{G}$ and T45G in adiponectin gene (66) and leptin G-2548A (67), as well as TNF-a G-308A (67) appeared to affect rosiglitazone efficacy and reversed IR in Chinese diabetic patients.

Treatment with TZDs has been particularly associated with high rates of developing fluid retention and peripheral edema, leading to congestive heart failure (52). Interestingly, a recent study done by Chang et al. (68) have suggested that rs296766 polymorphism of AQP2 gene coding aquaporin-2 (the vasopressin-regulated water channel), and rs12904216 polymorphism of SLC12A1 (the solute carrier protein family 12 group $A$, member one) gene coding the sodium-potassium-2 chloride 
TABLE 2. Summary of the gene polymorphisms involved in the pharmacogenetics of thiazolidinediones.

\begin{tabular}{|c|c|c|c|}
\hline SNP & Study population & Associated response phenotype & Reference \\
\hline \multicolumn{4}{|l|}{ PPARG } \\
\hline $\begin{array}{l}\text { Pro12Ala } \\
\text { (rs1801282) }\end{array}$ & $\begin{array}{l}\text { Patients with T2DM ( } \mathrm{N}=198) \text {, } \\
\text { 12-week rosiglitazone therapy. }\end{array}$ & $\begin{array}{l}\text { The decrease in FPG and HbA1c levels was significantly } \\
\text { greater in subjects with the Pro12Ala genotype, who had a } \\
\text { significantly better drug response. }\end{array}$ & $\begin{array}{l}\text { Kang et al, } \\
2005 \text { (63) }\end{array}$ \\
\hline \multicolumn{4}{|l|}{ PGC-1a } \\
\hline $\begin{array}{c}+1302 \mathrm{G}>\mathrm{A} \\
\text { (Thr394Thr) } \\
\text { (rs2970847) } \\
+1564 \mathrm{G}>\mathrm{A} \\
\text { (Gly482Ser) } \\
\text { (rs8192678) }\end{array}$ & $\begin{array}{l}\text { Patients with T2DM }(\mathrm{N}=41) \text {, } \\
\text { 12-week rosiglitazone therapy. }\end{array}$ & $\begin{array}{c}\text { Patients with the A or Ser variant were more likely to have a } \\
\text { negative response; patients with Gly482Gly genotype had } \\
\text { decreased FPG and PINS to a greater degree compared with } \\
\text { Gly482Ser + Ser482Ser genotype. }\end{array}$ & $\begin{array}{l}\text { Zhang et al, } \\
2010 \text { (64) }\end{array}$ \\
\hline
\end{tabular}

\begin{tabular}{cccc}
\hline Resistin & & \\
$-420 \mathrm{C}>\mathrm{G}$ & $\begin{array}{c}\text { Prospective study: T2DM patients } \\
\text { trs1862513) }\end{array}$ & The reduction of HbA1c correlated with the G/G genotype. & Makino et \\
& $\begin{array}{c}\text { Retrospective study: T2DM patients } \\
\text { treated with pioglitazone }(\mathrm{N}=63)\end{array}$ & \\
&
\end{tabular}

\begin{tabular}{|c|c|c|c|}
\hline Adiponectin & & & \\
\hline $\begin{array}{c}45 T>G \\
\text { (Gly15Gly) } \\
\text { (rs2241766) } \\
-11377 C>G \\
\text { (rs266729) }\end{array}$ & $\begin{array}{l}\text { Patients with T2DM }(\mathrm{N}=42) \text { treated } \\
12 \text { weeks with rosiglitazone. }\end{array}$ & $\begin{array}{l}\text { Attenuated effect in -11377CG +GG heterozygotes on FPG, } \\
\text { PPG, HOMA-IR compared with CC genotype; enhanced effect } \\
\text { in patients with - } 11377 / 45 \text { CGTT diplotype on FPG and PPG. }\end{array}$ & $\begin{array}{l}\text { Sun et al, } \\
2008(66)\end{array}$ \\
\hline
\end{tabular}

\begin{tabular}{|c|c|c|c|}
\hline \multicolumn{4}{|l|}{ Leptin } \\
\hline $\begin{array}{l}-2548 G>A \\
\text { (rs7799039) }\end{array}$ & $\begin{array}{l}\text { Patients with T2DM }(\mathrm{N}=42) \text { treated } \\
12 \text { weeks with rosiglitazone. }\end{array}$ & $\begin{array}{c}\text { Patients with G allele had significantly lower BMI and serum } \\
\text { leptin levels and increased FPG than patients with AA } \\
\text { genotype. }\end{array}$ & $\begin{array}{l}\text { Liu et al, } \\
2008(67)\end{array}$ \\
\hline \multicolumn{4}{|l|}{ TNF-alpha } \\
\hline $\begin{array}{c}-308 G>A \\
(r s 1800629)\end{array}$ & $\begin{array}{l}\text { Patients with } \mathrm{T} 2 \mathrm{DM}(\mathrm{N}=42) \text { treated } \\
12 \text { weeks with rosiglitazone. }\end{array}$ & $\begin{array}{l}\text { Attenuated effect in patients with GA+AA genotype on FINS } \\
\text { compared with GG genotype. }\end{array}$ & $\begin{array}{l}\text { Liu et al, } \\
2008(67)\end{array}$ \\
\hline \multicolumn{4}{|l|}{ CYP2C8 } \\
\hline $\begin{array}{l}\text { *3 (Arg139Lys } \\
\text { and Lys399Arg) } \\
\text { (rs10509681) }\end{array}$ & $\begin{array}{l}\text { Healthy volunteers }(\mathrm{N}=31) ; \text { a } \\
\text { single-dose rosiglitazone. }\end{array}$ & $\begin{array}{l}\text { Decreased mean total clearance, elimination half-lives, } \\
\text { and plasma glucose AUC; }{ }^{*} 3 \text { allele confers higher in vivo } \\
\text { metabolic capacity than the wild-type }{ }^{*} 1 \text { allele. }\end{array}$ & $\begin{array}{l}\text { Kirchheiner } \\
\text { et al, } 2006 \\
\text { (71) }\end{array}$ \\
\hline
\end{tabular}

transporter (NKCC2) with a key role in electrolyte movement across epithelia, represented risk factors for TZDs-associated edema. In addition to these genetic factors, the same study demonstrated that female gender and older age were also contributing factors to the edema development following TZDs treatment.

A recent study showed a diminished effect of pioglitazone treatment on glycemic control in patients with Ser447X polymorphism of gene encod- ing lipoprotein lipase (LPL), the enzyme responsible for the lipolytic processing of triglyceride-rich lipoproteins (61). CYP2C8 and CYP3A4 are the main DME catalyzing biotransformation of the pioglitazone (69), whereas rosiglitazone is metabolized by CYP2C8 and CYP2C9 (70). Genetic variation in CYP2C8 was found to be associated with altered clearance of rosiglitazone, with higher drug clearance in carriers of CYP2C8*3 allele coding for Arg139Lys and Lys399Arg amino acid substitutions (71). 


\section{Biguanides}

The biguanide drug metformin is recommended as the first-line therapy for T2DM (72). A main action of metformin is suppression of hepatic gluconeogenesis (73). Other antihyperglycemic effects include an increase of glucose uptake and utilization, improvement of insulin sensitivity, and reduction of intestinal glucose absorption (73). The molecular mechanisms of metformin action are not fully elucidated. It is believed that metformin increases the AMP/ATP ratio by specific inhibition of mitochondrial respiratory-chain complex 1 , which leads to the activation of adenosine monophosphate-activated protein kinase (AMPK) (74-77). Potential mechanism of AMPK phosphorylation by metformin includes the upstream serine-threonine kinase11 (STK11/LKB1) (78). However, a recent study showed that metformin could also inhibit gluconeogenesis in an AMPK-independent way (79).

Metformin is not metabolized but is excreted unchanged in urine by active tubular secretion (80). There is large variation in metformin renal clearance, and genetic factors contribute to this by more than $90 \%(81,82)$. Its oral absorption, hepatic uptake and renal elimination are mediated by carrier proteins (83). The intestinal absorption of metformin is probably mediated by plasma membrane monoamine transporter (PMAT, encoded by SLC29A4 gene), expressed on the luminal side of enterocytes (84). Organic cation transporter 1 (OCT1, encoded by SLC22A1 gene), expressed in the basolateral membrane of hepatocytes, mediates hepatic metformin uptake (85). OCT2 (encoded by SLC22A2), expressed primarily at the basolateral membrane in the kidney tubular cells, facilitates uptake of metformin into proximal tubule cells (86). The multidrug and toxin extrusion transporter 1 (MATE1, encoded by SLC47A1) and MATE2-K (encoded by SLC47A2), located in the apical membrane of the renal proximal tubule cells, facilitate metformin excretion from tubular cells into urine (87-89).

The therapeutic response to metformin is highly variable. In patients receiving metformin as an initial treatment for T2DM, less than two-thirds achieve desired glycemic control or the $\mathrm{HbA}_{1 \mathrm{c}}$ goal of $<7 \%(<53 \mathrm{mmol} / \mathrm{mol})$ (90). This implies that identification of genetic factors associated with treatment effectiveness could be relevant. The majority of pharmacogenetic studies of metformin response have investigated the effects of polymorphisms in the gene encoding OCT1, SLC22A1 (Table 3). OCT1 is necessary for metformin transport into the liver and subsequent metformin activity. Human SLC22A1 gene is highly polymorphic. Reduced-function polymorphisms of the SLC22A1 gene, such as R61C (rs12208357), G401S (rs34130495), 420del (rs72552763), and G465R (rs34059508) have been associated with lower effects of metformin in the oral glucose tolerance test (91). These same SNPs were also associated with a significantly higher metformin AUC, higher maximal plasma concentration and lower oral volume of distribution (92). However, a subsequent study demonstrated an additive increase in renal clearance of metformin with increasing number of reduced-function alleles (93). In a large population-based GoDARTS study the effects of R61C and 420del variants on initial glycemic response to metformin, the mid-term $\mathrm{HbA}_{1 c}$ control, and the rate of metformin monotherapy failure were not found (94). Another study analyzed the effects of 11 tagging SNPs in the SLC22A1 gene on HbA1c reduction, in a smaller cohort of incident users of metformin (95). A significant association of intronic rs622342 A>C SNP and lower HbA1c reduction was found (95).

A recent prospective study investigated the effects of variations in genes encoding OCT1, OCT2, MATE1, MATE2, and PMAT, on the trough steadystate plasma concentration (Css) of metformin and $\mathrm{HbA1c}$ change in T2DM patients treated with metformin (96). The mean trough Css of metformin, as well as the absolute decrease in $\mathrm{HbA1c}$ levels after 6 and 24 months, correlated conversely with the number of reduced-function SLC22A1 alleles (R61C, G401S, M420del and G465R) (96). It is hypothesized that in patients with reduced function OCT1 variants, less metformin is transported into hepatocytes and the volume of distribution decreases, resulting in a shorter half-life and lower trough Css of metformin (96). These results are in accordance 
TABLE 3. Summary of the gene polymorphisms involved in the pharmacogenetics of biguanides.

\begin{tabular}{|c|c|c|c|}
\hline SNP & Study population & Associated response phenotype & Reference \\
\hline \multicolumn{4}{|l|}{ SLC22A1 } \\
\hline \multirow{5}{*}{$\begin{array}{c}\text { R61C (Arg61Cys) (rs12208357) } \\
\text { G401S (Gly401Ser) (rs34130495) } \\
\text { 420del (rs72552763) } \\
\text { G465R (Gly465Arg) (rs34059508) }\end{array}$} & Healthy volunteers $(\mathrm{N}=21)$. & $\begin{array}{l}\text { Lower effects of metformin in the oral glucose } \\
\text { tolerance test. }\end{array}$ & $\begin{array}{l}\text { Shu et al, } \\
2007 \text { (91) }\end{array}$ \\
\hline & & & \\
\hline & Healthy volunteers $(\mathrm{N}=20)$. & $\begin{array}{c}\text { Higher metformin AUC, higher maximal } \\
\text { plasma concentration and lower oral volume of } \\
\text { distribution. }\end{array}$ & $\begin{array}{l}\text { Shu et al, } \\
2008(92)\end{array}$ \\
\hline & Healthy men $(N=103)$. & $\begin{array}{l}\text { Additive increase in renal clearance of } \\
\text { metformin with increasing number of } \\
\text { reduced-function alleles. }\end{array}$ & $\begin{array}{l}\text { Tzvetkov et } \\
\text { al, } 2009 \text { (93) }\end{array}$ \\
\hline & $\begin{array}{l}\text { Prospective study: T2DM } \\
\text { patients treated with } \\
\text { metformin }(\mathrm{N}=159) \text {. }\end{array}$ & $\begin{array}{l}\text { Inverse correlation of metformin trough Css and } \\
\text { reduction of } \mathrm{HbA1c} \text { levels with the number of } \\
\text { reduced-function SLC22A1 alleles. }\end{array}$ & $\begin{array}{l}\text { Christensen } \\
\text { et al, } 2011 \\
\text { (96) }\end{array}$ \\
\hline $\begin{array}{l}\text { R61C (Arg61Cys) (rs12208357) } \\
\text { 420del (rs72552763) }\end{array}$ & $\begin{array}{l}\text { Population-based GoDARTS } \\
\text { study: T2DM patients, incident } \\
\text { users of metformin }(\mathrm{N}=1.531) \text {. }\end{array}$ & $\begin{array}{l}\text { No effects on initial glycemic response to } \\
\text { metformin, the mid-term } \mathrm{HbA} 1 \mathrm{c} \text { control, and the } \\
\text { rate of metformin monotherapy failure. }\end{array}$ & $\begin{array}{c}\text { Zhou et al, } \\
2009 \text { (94) }\end{array}$ \\
\hline rs622342 A >C & $\begin{array}{l}\text { Population-based study: T2DM } \\
\text { patients, incident users of } \\
\text { metformin }(\mathrm{N}=102) \text {. }\end{array}$ & Lower $\mathrm{HbA1c}$ reduction. & $\begin{array}{c}\text { Becker et al, } \\
2009(95)\end{array}$ \\
\hline
\end{tabular}

\section{SLC22A2}

T199I (Thr199lle) (rs201919874)

T201M (Thr201Met)

(rs145450955)

A270S (Ala270Ser) (rs316019)

A270S (Ala270Ser) (rs316019)
Healthy subjects $(\mathrm{N}=26)$.

Increased metformin Cmax and AUC and reduced renal clearance of metformin.

Song et al, $2008(100)$

Healthy subjects $(N=15)$.

Reduced renal clearance of metformin.

Wang et al, 2008 (101)

Chen et al, 2009 (102)

\section{SLC47A1}

rs2289669 G>A

Population-based study: T2DM patients, incident users of metformin $(\mathrm{N}=116)$.

rs8065082 C>T

DPP study: individulas at high risk for T2DM randomized to placebo $(\mathrm{N}=1.000)$, metformin $(\mathrm{N}=990)$ or lifestyle intervention program $(\mathrm{N}=$ 1.004).
Increased metformin renal clearance.
Greater reduction of $\mathrm{HbA} 1 \mathrm{c}$ levels.

Becker et al, 2009 (103)

Lower diabetes incidence in subjects treated with metformin.
Jablonski et al, 2010

\section{SLC47A2}

rs12943590 G>A
Retrospective study: T2DM patients initially treated with metformin $(\mathrm{N}=253)$.

\section{ATM}

rs11212617 A >C
GWA study ( $\mathrm{N}=1.024)$ and two replication cohorts $(\mathrm{N}=1.783$ and $\mathrm{N}=1.113$ ) of $\mathrm{T} 2 \mathrm{D}$ patients, incident users of metformin.
Association with treatment success (achieving Zhou et al, an $\mathrm{HbA} 1 \mathrm{c}$ below $7 \%(53 \mathrm{mmol} / \mathrm{mol}))$, the combined odds ratio $=1.35$.
2011 (107)

AUC - area under the curve; $C_{s s}$ - steady-state plasma concentration; $C_{\max }-$ peak plasma concentration. 
with previous studies $(91,93)$. Replication of results regarding influence of OCT1 low-activity alleles on metformin pharmacokinetics and response, indicated that those variants could be useful pharmacogenetic markers for metformin therapy.

The first study on the association of genetic variations of OCT1, OCT2, and MATE1 transporters with gastrointestinal side effects of metformin therapy has been recently published (97). The minor alleles of rs628031 (M408V) and rs36056065 (8 bp insertion), which are two variants of the SLC22A1 gene in strong $L D$, were significantly associated with the presence of side effects (97). The local increase of drug concentration in the intestinal tissue is proposed as a mechanism of metformin intolerance (98). OCT1 and OCT3 (encoded by SLC22A3 gene) are also expressed in enterocytes (99), and although their role in the intestinal transport of metformin is not yet defined, authors suggest that SNPs in these genes may influence the intestinal metformin uptake and thus induce gastrointestinal side effects (97).

The results of the studies exploring the effect of the only common coding variant in the gene encoding OCT2 (SLC22A2), A270S (rs316019), on metformin clearance, have been contradictory. Two studies found significantly reduced renal clearance of metformin in homozygous variant carriers compared to wild-type homozygotes $(100,101)$. Interestingly, a separate study reported the opposite effect in individuals heterozygous for A270S variant who had higher metformin renal clearance as compared to the reference group (102). Christensen et al. (96) did not find the association between A270S and metformin trough Css or therapeutic response. However, given the importance of OCT2 in metformin pharmacokinetics, further pharmacogenetic studies are needed.

A preliminary study in the incident metformin users from the population-based Rotterdam study cohort assessed the influence of variations in MATE1-encoding gene, SLC47A1, on the HbA1c-lowering effect of metformin (103). From 12 tagging SNPs analyzed, the rs $2289669 \mathrm{G}>\mathrm{A}$ in intron 10 was associated with greater reduction in $\mathrm{HbA1c}$ levels (103). In a latter large-scale prospective clinical study (Diabetes Prevention Program, DPP) an asso- ciation of rs8065082 SNP in the SLC47A1 gene and lower diabetes incidence in subjects treated with metformin was found (104). This SNP was in high LD with rs2289669 G>A and thus, the DPP study confirmed the findings from a small preliminary study of Becker et al. (103). However, rs2289669 $\mathrm{G}>\mathrm{A}$ was not associated with metformin renal clearance (93), nor with metformin trough Css (96), and the mechanism underlying the impact of this SLC47A1 SNP remained unclear.

A recent study analyzed the effect of the MATE2-K gene (SLC47A2) polymorphism on glycemic response to metformin in newly diagnosed T2DM patients (105). A common 5'-UTR variant, g.-130G>A (rs12943590), was associated with enhanced promoter activity and weaker response to metformin, assessed by the relative $\mathrm{HbA1c}$ change (105). The study also explored the impact of OCT1, OCT2, and MATE1 variants on the initial metformin response. In line with previous studies $(103,104)$, the intronic rs2289669 G>A SNP in MATE1 gene was associated with higher $\mathrm{HbA1c}$ relative change, almost at the level of statistical significance (105).

In addition, other candidate genes which are likely to modulate metformin pharmacokinetics and response are genes encoding OCT3 (SLC22A3) and PMAT (SLC29A4) transporters. Recent in vitro study suggested that OCT3 is implicated in the uptake of metformin in muscle cells and its genetic variants may modulate metformin action (106). Genetic polymorphisms in PMAT showed a tendency of association with lower metformin trough concentration, and could be associated with decreased metformin absorption (96).

Recently, the first genome-wide association study (GWAS) on glycemic response to metformin in T2DM was performed. The study identified a common rs11212617 A>C SNP associated with treatment success in the large GWAS cohort (107), which was replicated in the two additional cohorts (107). The authors proposed that ATM (the ataxia telangiectasia mutated) gene, encoding a serine/ threonine protein kinase of the phosphoinositide 3-kinase-related protein kinase (PIKK) family, was the causative gene due to its association with IR, increased T2DM risk, and its role in AMPK activation (107). In general, additional studies are re- 
quired to identify genes involved in mechanisms of metformin pharmacological action.

\section{Meglitinides}

This class of short-acting insulin secretagogues acts by binding to $\beta$-cells and inhibiting KATP channel to stimulate insulin release. This is similar to the mechanism of action of the sulphonylureas and both, meglitinides (glinides) and SU, bind at two sites of the SUR1 subunit to inhibit channel activity (108). These two sites are thought to overlap to accommodate the negative charge and the central phenyl ring present in both, SU and meglitinides (109). Repaglinide is specifically designed to stimulate early insulin secretion in the postprandial period after binding to a distinct site on the $\beta$-cell (110). Similarly, nateglinide is an amino acid derivative that also induces an early insulin response to meals decreasing postprandial blood glucose levels. Due to their short action, meglitinides have a lower risk to induce hypoglycemia than SU. Furthermore, meglitinides offer an alternative OAD agent of similar potency to metformin, and may be indicated where side effects of metformin are intolerable or where metformin is contraindicated.

Gene polymorphisms associated with the variable meglitinides response are summarized in Table 4. A recent study showed that SLCO1B1 gene, which encodes the organic anion-transporting polypeptide 1B1 (OATP1B1), is a major determinant that markedly affects the repaglinide pharmacokinetics (111), consistent with an enhanced hepatic uptake by OATP1B1. SLCO1B1 521T>C SNP appeared to play an important role in the nateglinide pharmacokinetics (112). However, a study done by Kalliokoski et al. (113) found that, in contrast to repaglinide, the nateglinide disposition was not affected by the SLCO1B1 521T>C SNP. Furthermore, the same research group demonstrated that the $S L C O 1 B 1^{*} 1 B /{ }^{*} 1 B$ genotype was associated with reduced plasma levels of repaglinide, but had limited effects on the nateglinide disposition (114). A very recent study performed in healthy Chinese population have demonstrated that both, the 521T>C SNP of SLCO1B1 and CYP2C9*3 polymorphism, could significantly affect the nateglinide pharmacokinetics (115). However, these variants were not significantly associated with variations in its glucose-lowering effects and could only partially explain the interindividual variability of nateglinide plasma concentration (115).

Nateglinide is metabolized by CYP2C9 and moderate dose adjustments based on CYP2C9 genotypes may affect its pharmacokinetics (115) and interindividual variability in its antihyperglycemic effects (70). Repaglinide is metabolized by CYP2C8 and CYP3A4 (116) and, according to clinical studies, CYP2C8*3 carriers have higher clearance than carriers of the wild-type genotypes (70). However, recent study demonstrated that CYP2C8*3 did not appear to affect the repaglinide pharmacokinetics (117).

A recent pharmacogenetic study done in the Chinese population showed that the G2677T/A SNPs of MDR1 gene, encoding P-glycoprotein transporter, were associated with the variability in the repaglinide pharmacokinetics, suggesting that carriers of the MDR1 2677GT and TT allele might be exposed to higher levels of repaglinide (118).

Furthermore, Dai et al. (119) found that rs2237892 (C>T) and rs2237895 (C>A) SNPs, both located in intron 15 of KCNQ1 gene (120), encoding a voltagegated $\mathrm{K}+\mathrm{channel}$ expressed in the various tissues including pancreas, were associated with the repaglinide efficacy in Chinese T2DM patients. Diabetic patients carrying the rs2237892 risk $C$ allele had lower fasting insulin levels and HOMA-IR than those carrying the T allele. Furthermore, FPG and HOMA-IR levels were higher in T2DM patients with the $\mathrm{rs} 2237895$ risk $C$ allele compared with the carriers of the A allele. Interestingly, following repaglinide treatment, T2DM patients with the rs2237892 T allele and the rs2237895 C allele were more likely to have a positive effect on postprandial glucose levels than patients with the rs2237892 CC and rs2237895 AA genotype (119). In addition, a recent study performed by Yu et al. (121) demonstrated that Chinese T2DM patients, who were rs2237892 TT homozygotes, had lower glucose levels following repaglinide treatment, while the rs2237895 C risk allele in those patients was associated with greater increments in both, fasting insulin and $\mathrm{HO}$ MA-IR levels. 
TABLE 4. Summary of the gene polymorphisms involved in the pharmacogenetics of meglitinides.

\begin{tabular}{|c|c|c|c|}
\hline SNP & Study population & Associated response phenotype & Reference \\
\hline \multicolumn{4}{|l|}{ SLCO1B1 } \\
\hline \multirow[t]{3}{*}{$\begin{array}{l}521 \mathrm{~T}>\mathrm{C}(\text { Val174Ala }) \\
\quad(\text { rs4149056) }\end{array}$} & $\begin{array}{l}\text { Healthy volunteers }(\mathrm{N}=17) ; \text { a } \\
\text { single-dose of nateglinide. }\end{array}$ & $\begin{array}{c}\text { The Cmax and AUC of nateglinide were higher in the } \\
\text { subjects with the TC and CC genotype compared to the TT } \\
\text { genotype; the t } 1 / 2 \text { of nateglinide in CC subjects was longer } \\
\text { than in subjects with TT genotype. }\end{array}$ & $\begin{array}{l}\text { Zhang et al, } \\
2006(112)\end{array}$ \\
\hline & $\begin{array}{l}\text { Healthy volunteers }(\mathrm{N}=31) ; \mathrm{a} \\
\text { single-dose of nateglinide. }\end{array}$ & $\begin{array}{l}\text { Significant predictor of the AUC of nateglinide (a combined } \\
\text { effect with the CYP } 2 \text { C } 9 * 3 \text { ). }\end{array}$ & $\begin{array}{l}\text { Cheng et al, } \\
2012(115)\end{array}$ \\
\hline & $\begin{array}{l}\text { Healthy volunteers in two } \\
\text { studies }(\mathrm{N}=12) \text { and }(\mathrm{N}=32) ; \text { a } \\
\text { single-dose of repaglinide. }\end{array}$ & $\begin{array}{l}\text { AUC of repaglinide was larger in participants with the CC } \\
\text { genotype than in those with the TT genotype. }\end{array}$ & $\begin{array}{l}\text { Kalliokoski } \\
\text { et al, } 2008 \\
(111,113)\end{array}$ \\
\hline \multicolumn{4}{|l|}{ SLC30A8 } \\
\hline $\begin{array}{l}973 C>T(\text { Arg325Trp) } \\
(\text { rs13266634) } \\
974 G>A(\text { Arg325Gln }) \\
(\text { rs16889462) }\end{array}$ & $\begin{array}{l}\text { Patients with T2DM }(\mathrm{N}= \\
\text { 48) treated } 8 \text { weeks with } \\
\text { repaglinide. }\end{array}$ & $\begin{array}{l}\text { Better response on FINS and PINS in patients with } \\
\text { rs13266634 CT+TT genotypes compared with CC genotype. } \\
\text { In patients with rs16889462 GA genotype an enhanced } \\
\text { repaglinide efficacy on FPG, PPG, and HbA1c compared with } \\
\text { GG genotype. }\end{array}$ & $\begin{array}{l}\text { Huang et al, } \\
2010 \text { (122) }\end{array}$ \\
\hline
\end{tabular}

\section{MDR1}

2677G $>$ T/A Healthy volunteers $(\mathrm{N}=24)$;

(Ala893Ser/Thr) single-dose of repaglinide.
AUC of repaglinide was significantly higher in subjects with the GT and TT alleles than in those with the GG and TA alleles.
Xiang et al, 2012 (118) (rs2032582)

\section{KCNQ1}

rs2237892 C>T rs2237895 A $>C$
Patients with T2DM ( $=$

40) treated 8 weeks with repaglinide.

Patients with T2DM $(\mathrm{N}=$ 209) treated 8 weeks with repaglinide.
T2DM patients with the rs2237892 T allele and rs2237895 C allele were more likely to have a positive response in terms of PPG levels than T2DM patients with the rs2237892 CC and rs2237895 AA genotypes.

rs2237892 TT homozygotes exhibited lower 2-h glucose levels than the C allele carriers; rs2237892 C and rs2237895 $C$ alleles were associated with larger increase in FINS and HOMA-IR.
Dai et al, 2012 (119)

Yu et al, 2011 (121)

\section{KCNJ11}

$67 \mathrm{~A}>\mathrm{G}$ (Lys23Glu) (rs5219)
Patients with T2DM ( $\mathrm{N}=$

40) treated 8 weeks with repaglinide.
Patients with the GA or AA genotype showed higher levels of FPG, PPG, and HbA1c compared with patients with GG genotype.
Yu et al, $2010(123)$

\section{TCF7L2}

rs290487 C>T

Patients with T2DM ( $\mathrm{N}=$

In patients with the TT genotype, a better efficacy with

Yu et al,

40) treated 8 weeks with respect to FINS, triglycerides, and LDL-c compared to the CC $2010(123)$ repaglinide. or CT genotype.

\section{NAMPT}

-3186 C >T (rs11977021)
Patients with T2DM ( $\mathrm{N}=$

35) treated 8 weeks with repaglinide.
The elevated PINS in patients with CT genotypes of $-3186 \mathrm{C} / \mathrm{T}$ Sheng et al, were significantly lower than that in patients with the CC and 2011 (124) TT genotypes.

\section{CYP2C9}

*3 (Ile359Leu)

Healthy volunteers $(\mathrm{N}=31)$; a

Significant predictor of the AUC of nateglinide (a combined

Cheng et al,

(rs1057910)

single-dose of nateglinide.

effect with the SLCO1B1 521T>C).

2012 (115)

$\mathrm{C}_{\max }$ - maximum plasma concentration; AUC - area under the curve; $\mathrm{t}_{1 / 2}$ - elimination half-life; FINS - fasting insulin; PINS - postprandial insulin FPG - fasting plasma glucose; PPG - postprandial glucose; HOMA-IR - homeostasis model of assessment - insulin resistance; LDL-c - Iow-density lipoprotein cholesterol. 
Polymorphisms of the zinc transporter solute carrier family 30 member 8 gene (SLC30A8), including rs13266634 (973C>T, Arg325Trp) and rs16889462 (974G>A, Arg325GIn) SNPs, were recently reported to be related to T2DM development and importantly, to the repaglinide efficacy in Chinese T2DM patients (122). Patients with rs13266634 CT+TT genotypes showed decreased fasting and postprandial insulin levels compared to patients with CC genotype, while a significant differences in the decreased fasting and postprandial glucose and $\mathrm{HbA1c}$ levels were found between T2DM patients with GA and GG genotype of SLC30A8 rs16888462 SNP. Since SLC30A8 is mainly expressed in the pancreatic $\beta$-cells and appears to play a critical role during insulin maturation and release, the authors have speculated that SLC30A8 variations influence the zinc disposition and that KATP function, affecting the therapeutic efficacy of repaglinide (122).

Furthermore, the KCNJ11 and TCF7L2 polymorphisms seemed also to be associated with repaglinide efficacy in Chinese T2DM patients (123). Diabetic patients with the GA or AA genotype of the KCNJ11 Lys23Glu SNP showed higher levels of fasting and postprandial glucose and $\mathrm{HbA1c}$ following repaglinide treatment than in patients with the $G G$ genotype. On the other hand, in T2DM patients with the TT genotype of TCF7L2 rs290487 (C/T), the drug showed better efficacy with respect to levels of fasting insulin, triglycerides, and low-density lipoprotein cholesterol as compared to carriers of the CC or CT genotype (123).

A recent study performed by Sheng et al. (124) suggested that the $-3186 C>$ T SNP of gene encoding nicotinamide phosphoribosyltransferase (NAMPT) was significantly associated with postprandial insulin and total cholesterol levels in Chinese T2DM patients treated with repaglinide. Following the drug treatment, the elevated postprandial insulin levels as well as the total cholesterol levels in patients with CT genotype were significantly lower than in T2DM patients with the CC and TT genotype of the $-3186 C>T$ polymorphism (124).

\section{Conclusions}

In conclusion, the evidence has been accumulating to show that pharmacogenetics/pharmacoge- nomics has the potential to improve the management of T2DM and the effective OAD prescribing. Several variants related to drug-metabolizing enzymes, drug-transporters, drug target, and diabetes risk genes have been linked to interindividual differences in the OAD treatment outcomes. As summarized here, significant pharmacogenetic evidence has demonstrated an association between specific gene polymorphisms and interindividual variability in OAD therapeutic and side effects. Identification of drug-genotype interactions in pharmacogenetic studies of the OAD treatment might have clinical implications in the near future resulting in selection of more specific personalized therapy in T2DM. Although benefits from a personalized diabetes care are well established in patients with certain monogenic forms of diabetes, individualized treatment options in the more common polygenic forms of diabetes are also anticipated. However, it is also well understood that the diversity in drug effects cannot be explained by studying the genomic variations only and there are many potential barriers to the translation of pharmacogenetic findings to the antidiabetic treatment. Particularly, epigenomic research that focuses on nongenomic modifications influencing gene expression, may expand the scope of pharmacogenomics towards optimization of drug therapy. Recently introduced "miRNA-pharmacogenomics" that analyzes the polymorphisms in the miRNA regulatory pathway and its association with drug response, would also provide useful information for personalized medicine. Since the pharmacogenetic associations in diabetes that have been reported to date have had limited impact on the individual treatments choice, the value of genetic information in guiding therapeutic decisions in T2DM treatment must be further tested in adequately designed and rigorously conducted clinical trials. With recent scientific and technological advances, pharmacogenomics has a great potential to yield therapeutic advances leading the way towards personalized diabetes care.

\section{Potential conflict of interest}

None declared. 


\section{References}

1. Whiting DR, Guariguata L, Weil C, Shaw J. IDF diabetes atlas: global estimates of the prevalence of diabetes for 2011 and 2030. Diabetes Res Clin Pract 2011;94:311-21. http://dx.doi.org/10.1016/j.diabres.2011.10.029.

2. Hu L, Zhuo W, He YJ, Zhou HH, Fan L. Pharmacogenetics of P450 oxidoreductase: implications in drug metabolism and therapy. Pharmacogenet Genomics 2012;22:812-9. http:// dx.doi.org/10.1097/FPC.0b013e328358d92b.

3. McGraw J, Waller D. Cytochrome P450 variations in different ethnic populations. Expert Opin Drug Metab Toxicol 2012;8:371-82. http://dx.doi.org/10.1517/17425255.2012.6 57626.

4. Mannino GC, Sesti G. Individualized therapy for type 2 diabetes: clinical implications of pharmacogenetic data. Mol Diagn Ther 2012;16:285-302. http://dx.doi.org/10.1007/ s40291-012-0002-7.

5. Yoshida K, Maeda K, Sugiyama Y. Hepatic and Intestinal Drug Transporters: Prediction of Pharmacokinetic Effects Caused by Drug-Drug Interactions and Genetic Polymorphisms. Annu Rev Pharmacol Toxicol 2012; 53: 581-612. http://dx.doi.org/10.1146/annurev-pharmtox-011112140309.

6. Lai Y, Varma M, Feng B, Stephens JC, Kimoto E, El-Kattan A, et al. Impact of drug transporter pharmacogenomics on pharmacokinetic and pharmacodynamic variability - considerations for drug development. Expert Opin Drug Metab Toxicol 2012;8:723-43. http://dx.doi.org/10.1517/17425255 .2012.678048.

7. Gilbert ER, Liu D. Epigenetics: the missing link to understanding beta-cell dysfunction in the pathogenesis of type 2 diabetes. Epigenetics 2012;7:841-52. http://dx.doi. org/10.4161/epi.21238.

8. Zampetaki A, Kiech/ S, Drozdov I, Willeit P, Mayr U, Prokopi $M$, et al. Plasma microRNA profiling reveals loss of endothelial miR-126 and other microRNAs in type 2 diabetes. Circ Res 2010;107:810-7. http://dx.doi.org/10.1161/ CIRCRESAHA.110.226357.

9. Chen R, Mias GI, Li-Pook-Than J, Jiang L, Lam HY, Miriami $E$, et al. Personal omics profiling reveals dynamic molecular and medical phenotypes. Cell 2012;148:1293-307. http:// dx.doi.org/10.1016/j.cell.2012.02.009.

10. Johnson JA, Burkley BM, Langaee TY, Clare-Salzler MJ, Klein TE, Altman RB. Implementing personalized medicine: development of a cost-effective customized pharmacogenetics genotyping array. Clin Pharmacol Ther 2012;92:437-9. http://dx.doi.org/10.1038/clpt.2012.125.

11. McTaggart JS, Clark RH, Ashcroft FM. The role of the KATP channel in glucose homeostasis in health and disease: more than meets the islet. J Physiol 2010;588:3201-9. http://dx.doi.org/10.1113/jphysiol.2010.191767.

12. Flanagan SE, Clauin S, Bellanne-Chantelot $C$, de Lonlay $P$, Harries $L W$, Gloyn $A L$, et al. Update of mutations in the genes encoding the pancreatic beta-cell K(ATP) channel subunits Kir6.2 (KCNJ11) and sulfonylurea receptor 1 (ABCC8) in diabetes mellitus and hyperinsulinism. Hum Mutat 2009;30:170-80. http://dx.doi.org/10.1002/humu.20838.
13. Gloyn AL, Pearson ER, Antcliff JF, Proks P, Bruining GJ, Slingerland AS, et al. Activating mutations in the gene encoding the ATP-sensitive potassium-channel subunit Kir6.2 and permanent neonatal diabetes. NEngl J Med 2004;350:1838 49. http://dx.doi.org/10.1056/NEJMoa032922.

14. Pearson ER, Flechtner I, Njolstad PR, Malecki MT, Flanagan $S E$, Larkin B, et al. Switching from insulin to oral sulfonylureas in patients with diabetes due to Kir6.2 mutations. $N$ Engl J Med 2006;355:467-77. http://dx.doi.org/10.1056/ NEJMoa061759.

15. Zung A, Glaser B, Nimri R, Zadik Z. Glibenclamide treatment in permanent neonatal diabetes mellitus due to an activating mutation in Kir6.2. J Clin Endocrinol Metab 2004;89:5504-7. http://dx.doi.org/10.1210/jc.2004-1241.

16. Vaxillaire M, Veslot J, Dina C, Proenca C, Cauchi S, Charpentier $G$, et al. Impact of common type 2 diabetes risk polymorphisms in the DESIR prospective study. Diabetes 2008;57:244-54. http://dx.doi.org/10.2337/db07-0615.

17. Zhou D, Zhang D, Liu Y, Zhao T, Chen Z, Liu Z, et al. The E23K variation in the KCNJ11 gene is associated with type 2 diabetes in Chinese and East Asian population. J Hum Genet 2009;54:433-5. http://dx.doi.org/10.1038/jhg.2009.54.

18. Sesti G, Laratta E, Cardellini M, Andreozzi F, Del Guerra S, Irace $C$, et al. The E23K variant of KCNJ11 encoding the pancreatic beta-cell adenosine 5'-triphosphate-sensitive potassium channel subunit Kir6.2 is associated with an increased risk of secondary failure to sulfonylurea in patients with type 2 diabetes. J Clin Endocrinol Metab 2006;91:2334-9. http://dx.doi.org/10.1210/jc.2005-2323.

19. Villareal DT, Koster JC, Robertson H, Akrouh A, Miyake K, Bell Gl, et al. Kir6.2 variant E23K increases ATP-sensitive K+ channel activity and is associated with impaired insulin release and enhanced insulin sensitivity in adults with normal glucose tolerance. Diabetes 2009;58:1869-78. http:// dx.doi.org/10.2337/db09-0025.

20. Javorsky M, Klimcakova L, Schroner Z, Zidzik J, Babjakova E, Fabianova $M$, et al. KCNJ11 gene E23K variant and therapeutic response to sulfonylureas. Eur J Intern Med 2012;23:245-9. http://dx.doi.org/10.1016/j. ejim.2011.10.018.

21. Siklar Z, Ellard S, Okulu E, Berberoglu M, Young E, Savas Erdeve $S$, et al. Transient neonatal diabetes with two novel mutations in the KCNJ11 gene and response to sulfonylurea treatment in a preterm infant. J Pediatr Endocrinol Metab 2011;24:1077-80. http://dx.doi.org/10.1515/ JPEM.2011.250.

22. Dupont J, Pereira C, Medeira A, Duarte R, Ellard S, Sampaio L. Permanent neonatal diabetes mellitus due to KCNJ11 mutation in a Portuguese family: transition from insulin to oral sulfonylureas. J Pediatr Endocrinol Metab 2012;25:36770. http://dx.doi.org/10.1515/jpem-2011-0191.

23. Ellard S, Flanagan SE, Girard CA, Patch AM, Harries LW, Parrish $A$, et al. Permanent neonatal diabetes caused by dominant, recessive, or compound heterozygous SUR1 mutations with opposite functional effects. Am J Hum Genet 2007;81:375-82. http://dx.doi.org/10.1086/519174. 
24. Patch AM, Flanagan SE, Boustred C, Hattersley AT, Ellard S. Mutations in the ABCC8 gene encoding the SUR1 subunit of the KATP channel cause transient neonatal diabetes, permanent neonatal diabetes or permanent diabetes diagnosed outside the neonatal period. Diabetes Obes Metab 2007;9 Suppl 2:28-39. http://dx.doi.org/10.1111/j.14631326.2007.00772.x.

25. Feng Y, Mao G, Ren X, Xing H, Tang G, Li Q, et al. Ser1369Ala variant in sulfonylurea receptor gene $A B C C 8$ is associated with antidiabetic efficacy of gliclazide in Chinese type 2 diabetic patients. Diabetes Care 2008;31:1939-44. http:// dx.doi.org/10.2337/dc07-2248.

26. Holstein JD, Kovacs P, Patzer O, Stumvoll $M$, Holstein A. The Ser1369Ala variant of ABCC8 and the risk for severe sulfonylurea-induced hypoglycemia in German patients with Type 2 diabetes. Pharmacogenomics 2012;13:5-7; author reply 9-10. http://dx.doi.org/10.2217/pgs.11.150.

27. Sato R, Watanabe H, Genma R, Takeuchi M, Maekawa M, Nakamura H. ABCC8 polymorphism (Ser1369Ala): influence on severe hypoglycemia due to sulfonylureas. Pharmacogenomics 2010;11:1743-50. http://dx.doi.org/10.2217/ pgs. 10.135 .

28. Nikolac N, Simundic AM, Katalinic D, Topic E, Cipak A, Zjacic Rotkvic V. Metabolic control in type 2 diabetes is associated with sulfonylurea receptor-1 (SUR-1) but not with KCNJ11 polymorphisms. Arch Med Res 2009;40:387-92. http://dx.doi.org/10.1016/j.arcmed.2009.06.006.

29. Nikolac $N$, Simundic AM, Saracevic A, Katalinic D. ABCC8 polymorphisms are associated with triglyceride concentration in type 2 diabetics on sulfonylurea therapy. Genet Test Mol Biomarkers 2012;16:924-30. http://dx.doi.org/10.1089/ gtmb.2011.0337.

30. Meirhaeghe A, Helbecque N, Cottel D, Arveiler D, Ruidavets $J B$, Haas $B$, et al. Impact of sulfonylurea receptor 1 genetic variability on non-insulin-dependent diabetes mellitus prevalence and treatment: a population study. Am J Med Genet 2001;101:4-8. http://dx.doi.org/10.1002/ajmg.1297.

31. Fatehi $M$, Raja $M$, Carter $C$, Soliman $D$, Holt $A$, Light PE. The ATP-sensitive $K(+)$ channel ABCC8 S1369A type 2 diabetes risk variant increases MgATPase activity. Diabetes 2012;61:241-9. http://dx.doi.org/10.2337/db11-0371.

32. Lang VY, Fatehi M, Light PE. Pharmacogenomic analysis of ATP-sensitive potassium channels coexpressing the common type 2 diabetes risk variants E23K and S1369A. Pharmacogenet Genomics 2012;22:206-14. http://dx.doi. org/10.1097/FPC.0b013e32835001e7.

33. Pearson ER, Liddell WG, Shepherd M, Corrall RJ, Hattersley AT. Sensitivity to sulphonylureas in patients with hepatocyte nuclear factor-1alpha gene mutations: evidence for pharmacogenetics in diabetes. Diabet Med 2000;17:543-5. http://dx.doi.org/10.1046/j.1464-5491.2000.00305.x.

34. Schroner Z, Dobrikova M, Klimcakova L, Javorsky M, Zidzik J, Kozarova M, et al. Variation in KCNQ1 is associated with therapeutic response to sulphonylureas. Med Sci Monit 2011;17:CR392-6. http://dx.doi.org/10.12659/ MSM.881850.
35. Sesti G, Marini MA, Cardellini M, Sciacqua A, Frontoni S, Andreozzi $F$, et al. The Arg972 variant in insulin receptor substrate-1 is associated with an increased risk of secondary failure to sulfonylurea in patients with type 2 diabetes. Diabetes Care 2004;27:1394-8. http://dx.doi.org/10.2337/ diacare.27.6.1394.

36. Clatworthy JP, Subramanian V. Stem cells and the regulation of proliferation, differentiation and patterning in the intestinal epithelium: emerging insights from gene expression patterns, transgenic and gene ablation studies. Mech Dev 2001;101:3-9. http://dx.doi.org/10.1016/S0925-4773(00)00557-8.

37. Cauchi S, El Achhab Y, Choquet H, Dina C, Krempler F, Weitgasser $R$, et al. TCF7L2 is reproducibly associated with type 2 diabetes in various ethnic groups: a global meta-analysis. J Mol Med (Berl) 2007;85:777-82. http://dx.doi.org/10.1007/ s00109-007-0203-4.

38. Tong $Y$, Lin $Y$, Zhang $Y$, Yang J, Liu H, Zhang B. Association between TCF7L2 gene polymorphisms and susceptibility to type 2 diabetes mellitus: a large Human Genome Epidemiology (HuGE) review and meta-analysis. BMC Med Genet 2009;10:15. http://dx.doi.org/10.1186/1471-2350-10-15.

39. Schroner Z, Javorsky M, Tkacova R, Klimcakova L, Dobrikova $M$, Habalova $V$, et al. Effect of sulphonylurea treatment on glycaemic control is related to TCF7L2 genotype in patients with type 2 diabetes. Diabetes Obes Metab 2011;13:8991. http://dx.doi.org/10.1111/j.1463-1326.2010.01324.x.

40. Pearson ER, Donnelly LA, Kimber C, Whitley A, Doney AS, McCarthy MI, et al. Variation in TCF7L2 influences therapeutic response to sulfonylureas: a GoDARTs study. Diabetes 2007;56:2178-82. http://dx.doi.org/10.2337/db07-0440.

41. Holstein A, Hahn M, Korner A, Stumvoll M, Kovacs P. TCF7L2 and therapeutic response to sulfonylureas in patients with type 2 diabetes. BMC Med Genet 2011;12:30. http://dx.doi. org/10.1186/1471-2350-12-30.

42. Becker ML, Visser LE, Trienekens PH, Hofman A, van Schaik $\mathrm{RH}$, Stricker BH. Cytochrome P450 2C9*2 and *3 polymorphisms and the dose and effect of sulfonylurea in type II diabetes mellitus. Clin Pharmacol Ther 2008;83:288-92. http:// dx.doi.org/10.1038/sj.clpt.6100273.

43. Ragia G, Petridis I, Tavridou A, Christakidis D, Manolopoulos VG. Presence of CYP2C9*3 allele increases risk for hypoglycemia in Type 2 diabetic patients treated with sulfonylureas. Pharmacogenomics 2009;10:1781-7. http://dx.doi. org/10.2217/pgs.09.96.

44. Semiz S, Dujic T, Ostanek B, Prnjavorac B, Bego T, Malenica $M$, et al. Analysis of CYP2C9*2, CYP2C19*2, and CYP2D6*4 polymorphisms in patients with type 2 diabetes mellitus. Bosn J Basic Med Sci 2010;10:287-91.

45. Holstein A, Plaschke A, Ptak M, Egberts EH, El-Din J, Brockmoller J, et al. Association between CYP2C9 slow metabolizer genotypes and severe hypoglycaemia on medication with sulphonylurea hypoglycaemic agents. Br J Clin Pharmacol 2005;60:103-6. http://dx.doi.org/10.1111/j.13652125.2005.02379.x. 
46. Bozkurt O, de Boer A, Grobbee DE, Heerdink ER, Burger $\mathrm{H}$, Klungel $\mathrm{OH}$. Pharmacogenetics of glucose-lowering drug treatment: a systematic review. Mol Diagn Ther 2007;11:291-302. http://dx.doi.org/10.1007/BF03256250.

47. Distefano JK, Watanabe RM. Pharmacogenetics of AntiDiabetes Drugs. Pharmaceuticals (Basel) 2010;3:2610-46. http://dx.doi.org/10.3390/ph3082610.

48. Kirchheiner J, Brockmoller J, Meineke I, Bauer S, Rohde W, Meisel C, et al. Impact of CYP2C9 amino acid polymorphisms on glyburide kinetics and on the insulin and glucose response in healthy volunteers. Clin Pharmacol Ther 2002;71:286-96. http://dx.doi.org/10.1067/ mcp.2002.122476.

49. Niemi M, Cascorbi I, Timm R, Kroemer HK, Neuvonen PJ, Kivisto KT. Glyburide and glimepiride pharmacokinetiCs in subjects with different CYP2C9 genotypes. Clin Pharmacol Ther 2002;72:326-32. http://dx.doi.org/10.1067/ mcp.2002.127495.

50. Swen JJ, Wessels JA, Krabben A, Assendelft WJ, Guchelaar HJ. Effect of CYP2C9 polymorphisms on prescribed dose and time-to-stable dose of sulfonylureas in primary care patients with Type 2 diabetes mellitus. Pharmacogenomics 2010;11:1517-23. http://dx.doi.org/10.2217/pgs.10.121.

51. Zhou K, Donnelly L, Burch L, Tavendale R, Doney AS, Leese $G$, et al. Loss-of-function CYP2C9 variants improve therapeutic response to sulfonylureas in type 2 diabetes: a GoDARTS study. Clin Pharmacol Ther 2010;87:52-6. http:// dx.doi.org/10.1038/clpt.2009.176.

52. Karalliedde J, Buckingham RE. Thiazolidinediones and their fluid-related adverse effects: facts, fiction and putative management strategies. Drug Saf 2007;30:741-53. http:// dx.doi.org/10.2165/00002018-200730090-00002.

53. Nissen SE, Wolski K. Effect of rosiglitazone on the risk of myocardial infarction and death from cardiovascular causes. N Engl J Med 2007;356:2457-71. http://dx.doi. org/10.1056/NEJMoa072761.

54. Chen X, Yang L, Zhai SD. Risk of cardiovascular disease and all-cause mortality among diabetic patients prescribed rosiglitazone or pioglitazone: a meta-analysis of retrospective cohort studies. Chin Med J (Engl) 2012;125:4301-6.

55. Derosa G. Pioglitazone is a valid alternative to rosiglitazone. Am J Cardiovasc Drugs 2011;11:357-62. http://dx.doi. org/10.2165/11595990-000000000-00000.

56. Tolman KG. The safety of thiazolidinediones. Expert Opin Drug Saf 2011;10:419-28. http://dx.doi.org/10.1517/14740 338.2011.534982.

57. Mizushige K, Tsuji T, Noma T. Pioglitazone: cardiovascular effects in prediabetic patients. Cardiovasc Drug Rev 2002;20:329-40. http://dx.doi.org/10.1111/j.15273466.2002.tb00100.x.

58. Kermode-Scott B. Meta-analysis confirms raised risk of bladder cancer from pioglitazone. BMJ 2012;345:e4541. http://dx.doi.org/10.1136/bmj.e4541.

59. Clyne M. Bladder cancer: Pioglitazone increases risk of bladder cancer. Nat Rev Urol 2012;9:353. http://dx.doi. org/10.1038/nrurol.2012.131.
60. Colmers IN, Bowker SL, Majumdar SR, Johnson JA. Use of thiazolidinediones and the risk of bladder cancer among people with type 2 diabetes: a meta-analysis. CMAJ 2012;184:E675-83. http://dx.doi.org/10.1503/cmaj.112102.

61. Schroner Z, Javorsky M, Kozarova M, Tkac I. Pharmacogenetics of oral antidiabetic treatment. Bratisl Lek Listy 2011;112:441-6.

62. Barroso I, Gurnell M, Crowley VE, Agostini M, Schwabe JW, Soos $M A$, et al. Dominant negative mutations in human PPARgamma associated with severe insulin resistance, diabetes mellitus and hypertension. Nature 1999;402:880-3.

63. Kang ES, Park SY, Kim HJ, Kim CS, Ahn CW, Cha BS, et al. Effects of Pro12Ala polymorphism of peroxisome proliferatoractivated receptor gamma2 gene on rosiglitazone response in type 2 diabetes. Clin Pharmacol Ther 2005;78:202-8. http://dx.doi.org/10.1016/j.clpt.2005.04.013.

64. Zhang KH, Huang Q, Dai XP, Yin JY, Zhang W, Zhou G, et al. Effects of the peroxisome proliferator activated receptor-gamma coactivator-1alpha (PGC-1alpha) Thr394T$\mathrm{hr}$ and Gly482Ser polymorphisms on rosiglitazone response in Chinese patients with type 2 diabetes mellitus. J Clin Pharmacol 2010;50:1022-30. http://dx.doi. org/10.1177/0091270009355159.

65. Makino H, Shimizu I, Murao S, Kondo S, Tabara Y, Fujiyama $M$, et al. A pilot study suggests that the $G / G$ genotype of resistin single nucleotide polymorphism at -420 may be an independent predictor of a reduction in fasting plasma glucose and insulin resistance by pioglitazone in type 2 diabetes. Endocr J 2009;56:1049-58. http://dx.doi.org/10.1507/ endocrj.K08E-320.

66. Sun H, Gong ZC, Yin JY, Liu HL, Liu YZ, Guo ZW, et al. The association of adiponectin allele 45T/G and -11377C/G polymorphisms with Type 2 diabetes and rosiglitazone response in Chinese patients. Br J Clin Pharmacol 2008;65:91726. http://dx.doi.org/10.1111/j.1365-2125.2008.03145.x.

67. Liu HL, Lin YG, Wu J, Sun H, Gong ZC, Hu PC, et al. Impact of genetic polymorphisms of leptin and TNF-alpha on rosiglitazone response in Chinese patients with type 2 diabetes. Eur J Clin Pharmacol 2008;64:663-71. http://dx.doi. org/10.1007/s00228-008-0483-9.

68. Chang TJ, Liu PH, Liang YC, Chang YC, Jiang YD, Li HY, et al. Genetic predisposition and nongenetic risk factors of thiazolidinedione-related edema in patients with type 2 diabetes. Pharmacogenet Genomics 2011;21:829-36. http:// dx.doi.org/10.1097/FPC.0b013e32834bfff1.

69. Jaakkola T, Laitila J, Neuvonen PJ, Backman JT. Pioglitazone is metabolised by CYP2C8 and CYP3A4 in vitro: potential for interactions with CYP2C8 inhibitors. Basic Clin Pharmacol Toxicol 2006;99:44-51. http://dx.doi.org/10.1111/ j.1742-7843.2006.pto_437.x.

70. Kirchheiner J, Roots I, Goldammer M, Rosenkranz B, Brockmoller J. Effect of genetic polymorphisms in cytochrome p450 (CYP) 2C9 and CYP2C8 on the pharmacokinetics of oral antidiabetic drugs: clinical relevance. Clin Pharmacokinet 2005;44:1209-25. http://dx.doi.org/10.2165/00003088200544120-00002. 
71. Kirchheiner J, Thomas S, Bauer S, Tomalik-Scharte D, Hering $U$, Doroshyenko $O$, et al. Pharmacokinetics and pharmacodynamics of rosiglitazone in relation to CYP2C8 genotype. Clin Pharmacol Ther 2006;80:657-67. http://dx.doi. org/10.1016/j.clpt.2006.09.008.

72. Standards of medical care in diabetes--2012. Diabetes Care 2012;35 Suppl 1:S11-63. http://dx.doi.org/10.2337/dc12s011.

73. Kirpichnikov D, McFarlane SI, Sowers JR. Metformin: an update. Ann Intern Med 2002;137:25-33.

74. Zhou G, Myers R, Li Y, Chen Y, Shen X, Fenyk-Melody J, et al. Role of AMP-activated protein kinase in mechanism of metformin action. J Clin Invest 2001;108:1167-74.

75. El-Mir MY, Nogueira V, Fontaine E, Averet N, Rigoulet M, Leverve $X$. Dimethylbiguanide inhibits cell respiration via an indirect effect targeted on the respiratory chain complex I. J Biol Chem 2000;275:223-8. http://dx.doi.org/10.1074/ jbc.275.1.223.

76. Owen MR, Doran E, Halestrap AP. Evidence that metformin exerts its anti-diabetic effects through inhibition of complex 1 of the mitochondrial respiratory chain. Biochem J 2000;348 Pt 3:607-14. http://dx.doi.org/10.1042/02646021:3480607.

77. Viollet B, Guigas B, Sanz Garcia N, Leclerc J, Foretz M, Andreelli F. Cellular and molecular mechanisms of metformin: an overview. Clin Sci (Lond) 2012;122:253-70. http://dx.doi. org/10.1042/CS20110386.

78. Shaw RJ, Lamia KA, Vasquez D, Koo SH, Bardeesy N, Depinho $R A$, et al. The kinase LKB1 mediates glucose homeostasis in liver and therapeutic effects of metformin. Science 2005;310:1642-6. http://dx.doi.org/10.1126/science. 1120781.

79. Foretz M, Hebrard S, Leclerc J, Zarrinpashneh E, Soty M, Mithieux $G$, et al. Metformin inhibits hepatic gluconeogenesis in mice independently of the LKB1/AMPK pathway via a decrease in hepatic energy state. J Clin Invest 2010;120:235569. http://dx.doi.org/10.1172/JCl40671.

80. Robert F, Fendri S, Hary L, Lacroix C, Andrejak M, Lalau JD. Kinetics of plasma and erythrocyte metformin after acute administration in healthy subjects. Diabetes Metab 2003;29:279-83. http://dx.doi.org/10.1016/S1262-3636(07)70037-X.

81. Leabman MK, Giacomini KM. Estimating the contribution of genes and environment to variation in renal drug clearance. Pharmacogenetics 2003;13:581-4. http://dx.doi. org/10.1097/00008571-200309000-00007.

82. Yin OQ, Tomlinson B, Chow MS. Variability in renal clearance of substrates for renal transporters in chinese subjects. J Clin Pharmacol 2006;46:157-63. http://dx.doi. org/10.1177/0091270005283838.

83. Graham GG, Punt J, Arora M, Day RO, Doogue MP, Duong JK, et al. Clinical pharmacokinetics of metformin. Clin Pharmacokinet 2011;50:81-98. http://dx.doi. org/10.2165/11534750-000000000-00000.

84. Zhou M, Xia L, Wang J. Metformin transport by a newly cloned proton-stimulated organic cation transporter (plasma membrane monoamine transporter) expressed in human intestine. Drug Metab Dispos 2007;35:1956-62. http:// dx.doi.org/10.1124/dmd.107.015495.
85. Wang DS, Jonker JW, Kato Y, Kusuhara H, Schinkel AH, Sugiyama $Y$. Involvement of organic cation transporter 1 in hepatic and intestinal distribution of metformin. J Pharmacol Exp Ther 2002;302:510-5. http://dx.doi.org/10.1124/ jpet.102.034140.

86. Kimura $N$, Okuda $M$, Inui K. Metformin transport by renal basolateral organic cation transporter hOCT2. Pharm Res 2005;22:255-9. http://dx.doi.org/10.1007/s11095-0041193-3.

87. Otsuka M, Matsumoto T, Morimoto R, Arioka S, Omote $H$, Moriyama $Y$. A human transporter protein that mediates the final excretion step for toxic organic cations. Proc Natl Acad Sci U S A 2005;102:17923-8. http://dx.doi. org/10.1073/pnas.0506483102.

88. Masuda S, Terada T, Yonezawa A, Tanihara Y, Kishimoto $K$, Katsura $T$, et al. Identification and functional characterization of a new human kidney-specific $\mathrm{H}+$ /organic cation antiporter, kidney-specific multidrug and toxin extrusion 2. J Am Soc Nephrol 2006;17:2127-35. http://dx.doi. org/10.1681/ASN.2006030205.

89. Kusuhara $H$, Ito $S$, Kumagai $Y$, Jiang M, Shiroshita T, Moriyama $Y$, et al. Effects of a MATE protein inhibitor, pyrimethamine, on the renal elimination of metformin at oral microdose and at therapeutic dose in healthy subjects. Clin Pharmacol Ther 2011;89:837-44. http://dx.doi.org/10.1038/ clpt.2011.36.

90. Kahn SE, Haffner SM, Heise MA, Herman WH, Holman RR, Jones NP, et al. Glycemic durability of rosiglitazone, metformin, or glyburide monotherapy. N Engl J Med 2006;355:2427-43. http://dx.doi.org/10.1056/NEJMoa066224.

91. Shu Y, Sheardown SA, Brown C, Owen RP, Zhang S, Castro $R A$, et al. Effect of genetic variation in the organic cation transporter 1 (OCT1) on metformin action. J Clin Invest 2007;117:1422-31. http://dx.doi.org/10.1172/JCl30558.

92. Shu Y, Brown C, Castro RA, Shi RJ, Lin ET, Owen RP, et al. Effect of genetic variation in the organic cation transporter 1, OCT1, on metformin pharmacokinetics. Clin Pharmacol Ther 2008;83:273-80. http://dx.doi.org/10.1038/ sj.clpt.6100275.

93. Tzvetkov MV, Vormfelde SV, Balen D, Meineke I, Schmidt $T$, Sehrt $D$, et al. The effects of genetic polymorphisms in the organic cation transporters OCT1, OCT2, and OCT3 on the renal clearance of metformin. Clin Pharmacol Ther 2009;86:299-306. http://dx.doi.org/10.1038/clpt.2009.92.

94. Zhou K, Donnelly LA, Kimber CH, Donnan PT, Doney AS, Leese $G$, et al. Reduced-function SLC22A1 polymorphisms encoding organic cation transporter 1 and glycemic response to metformin: a GoDARTS study. Diabetes 2009;58:1434-9. http://dx.doi.org/10.2337/db08-0896.

95. Becker ML, Visser $L E$, van Schaik RH, Hofman A, Uitterlinden $A G$, Stricker $B H$. Genetic variation in the organic cation transporter 1 is associated with metformin response in patients with diabetes mellitus. Pharmacogenomics $J$ 2009;9:242-7. http://dx.doi.org/10.1038/tpj.2009.15.

96. Christensen MM, Brasch-Andersen C, Green H, Nielsen F, Damkier P, Beck-Nielsen $H$, et al. The pharmacogenetics of metformin and its impact on plasma metformin steady-state levels and glycosylated hemoglobin A1c. Pharmacogenet Genomics 2011;21:837-50. http://dx.doi.org/10.1097/ FPC.0b013e32834c0010. 
97. Tarasova L, Kalnina I, Geldnere K, Bumbure A, Ritenberga $R$, Nikitina-Zake $L$, et al. Association of genetic variation in the organic cation transporters OCT1, OCT2 and multidrug and toxin extrusion 1 transporter protein genes with the gastrointestinal side effects and lower BMI in metformin-treated type 2 diabetes patients. Pharmacogenet Genomics 2012;22:659-66. http://dx.doi.org/10.1097/ FPC.0b013e3283561666.

98. Wilcock C, Bailey CJ. Accumulation of metformin by tissues of the normal and diabeticmouse.Xenobiotica 1994;24:4957. http://dx.doi.org/10.3109/00498259409043220.

99. Muller J, Lips KS, Metzner L, Neubert RH, Koepsell H, Brandsch M. Drug specificity and intestinal membrane localization of human organic cation transporters (OCT). Biochem Pharmacol 2005;70:1851-60. http://dx.doi. org/10.1016/j.bcp.2005.09.011.

100. Song IS, Shin HJ, Shim EJ, Jung IS, Kim WY, Shon JH, et al. Genetic variants of the organic cation transporter 2 influence the disposition of metformin. Clin Pharmacol Ther 2008;84:559-62. http://dx.doi.org/10.1038/clpt.2008.61.

101. Wang ZJ, Yin OQ, Tomlinson B, Chow MS. OCT2 polymorphisms and in-vivo renal functional consequence: studies with metformin and cimetidine. Pharmacogenet Genomics 2008;18:637-45. http://dx.doi.org/10.1097/ FPC.0b013e328302cd41.

102. Chen Y, Li S, Brown C, Cheatham S, Castro RA, Leabman $M K$, et al. Effect of genetic variation in the organic cation transporter 2 on the renal elimination of metformin. Pharmacogenet Genomics 2009;19:497-504. http:// dx.doi.org/10.1097/FPC.0b013e32832cc7e9.

103. Becker ML, Visser LE, van Schaik RH, Hofman A, Uitterlinden $A G$, Stricker BH. Genetic variation in the multidrug and toxin extrusion 1 transporter protein influences the glucose-lowering effect of metformin in patients with diabetes: a preliminary study. Diabetes 2009;58:745-9. http:// dx.doi.org/10.2337/db08-1028.

104. Jablonski KA, McAteer JB, de Bakker Pl, Franks PW, PoIlin TI, Hanson RL, et al. Common variants in 40 genes assessed for diabetes incidence and response to metformin and lifestyle intervention in the diabetes prevention program. Diabetes 2010;59:2672-81. http://dx.doi. org/10.2337/db10-0543.

105. Choi JH, Yee SW, Ramirez AH, Morrissey KM, Jang GH, Joski PJ, et al. A common 5'-UTR variant in MATE2-K is associated with poor response to metformin. Clin Pharmacol Ther 2011;90:674-84. http://dx.doi.org/10.1038/ clpt.2011.165.

106. Chen L, Pawlikowski B, Schlessinger A, More SS, Stryke $D$, Johns SJ, et al. Role of organic cation transporter 3 (SLC22A3) and its missense variants in the pharmacologic action of metformin. Pharmacogenet Genomics 2010;20:687-99. http://dx.doi.org/10.1097/ FPC.0b013e32833fe789.

107. Zhou K, Bellenguez C, Spencer CC, Bennett AJ, Coleman $R L$, Tavendale $R$, et al. Common variants near ATM are associated with glycemic response to metformin in type 2 diabetes. Nat Genet 2011;43:117-20. http://dx.doi. org/10.1038/ng.735.
108. Yan FF, Casey J, Shyng SL. Sulfonylureas correct trafficking defects of disease-causing ATP-sensitive potassium channels by binding to the channel complex. J Biol Chem 2006;281:33403-13. http://dx.doi.org/10.1074/jbc. M605195200.

109. Brown GR, Foubister AJ. Receptor binding sites of hypoglycemic sulfonylureas and related [(acylamino)alkyl] benzoic acids. J Med Chem 1984;27:79-81. http://dx.doi. org/10.1021/jm00367a016.

110. Fuhlendorff J, Rorsman $P$, Kofod $H$, Brand $C L$, Rolin $B$, Mackay $P$, et al. Stimulation of insulin release by repaglinide and glibenclamide involves both common and distinct processes. Diabetes 1998;47:345-51. http://dx.doi. org/10.2337/diabetes.47.3.345.

111. Kalliokoski A, Neuvonen M, Neuvonen PJ, Niemi M. The effect of SLCO1B1 polymorphism on repaglinide pharmacokinetics persists over a wide dose range. Br J Clin Pharmacol 2008;66:818-25. http://dx.doi.org/10.1111/j.13652125.2008.03287.x.

112. Zhang $W$, He YJ, Han CT, Liu ZQ, Li Q, Fan L, et al. Effect of SLCO1B1 genetic polymorphism on the pharmacokinetics of nateglinide. Br J Clin Pharmacol 2006;62:567-72. http://dx.doi.org/10.1111/j.1365-2125.2006.02686.x.

113. Kalliokoski A, Neuvonen $M$, Neuvonen PJ, Niemi M. Different effects of SLCO1B1 polymorphism on the pharmacokinetics and pharmacodynamics of repaglinide and nateglinide. J Clin Pharmacol 2008;48:311-21. http://dx.doi. org/10.1177/0091270007311569.

114. Kalliokoski A, Backman JT, Neuvonen PJ, Niemi M. Effects of the SLCO1B1*1B haplotype on the pharmacokinetics and pharmacodynamics of repaglinide and nateglinide. Pharmacogenet Genomics 2008;18:937-42. http://dx.doi. org/10.1097/FPC.0b013e32830d733e.

115. Cheng Y, Wang G, Zhang W, Fan L, Chen Y, Zhou HH. Effect of CYP2C9 and SLCO1B1 polymorphisms on the pharmacokinetics and pharmacodynamics of nateglinide in healthy Chinese male volunteers. Eur J Clin Pharmacol 2013;69:40713. $h$ ttp://dx.doi.org/10.1007/s00228-012-1364-9.

116. Bidstrup TB, Bjornsdottir I, Sidelmann UG, Thomsen MS, Hansen KT. CYP2C8 and CYP3A4 are the principal enzymes involved in the human in vitro biotransformation of the insulin secretagogue repaglinide. Br J Clin Pharmacol 2003;56:305-14. http://dx.doi.org/10.1046/j.03065251.2003.01862.x.

117. Tomalik-Scharte $D$, Fuhr U, Hellmich M, Frank D, Doroshyenko $O$, Jetter $A$, et al. Effect of the CYP2C8 genotype on the pharmacokinetics and pharmacodynamics of repaglinide. Drug Metab Dispos 2011;39:927-32. http:// dx.doi.org/10.1124/dmd.110.036921.

118. Xiang Q, Cui YM, Zhao X, Yan L, Zhou Y. The Influence of MDR1 G2677T/a genetic polymorphisms on the pharmacokinetics of repaglinide in healthy Chinese volunteers. Pharmacology 2012;89:105-10. http://dx.doi. org/10.1159/000336345.

119. Dai XP, Huang $Q$, Yin JY, Guo Y, Gong ZC, Lei $M X$, et al. $K C N Q 1$ gene polymorphisms are associated with the therapeutic efficacy of repaglinide in Chinese Type 2 diabetic patients. Clin Exp Pharmacol Physiol 2012;39:462-8. http://dx.doi.org/10.1111/j.1440-1681.2012.05701.x. 
120. Yasuda K, Miyake K, Horikawa Y, Hara K, Osawa H, Furuta $H$, et al. Variants in KCNQ1 are associated with susceptibility to type 2 diabetes mellitus. Nat Genet 2008;40:1092-7. http://dx.doi.org/10.1038/ng.207.

121. Yu W, Hu C, Zhang R, Wang C, Qin W, Lu J, et al. Effects of KCNQ1 polymorphisms on the therapeutic efficacy of oral antidiabetic drugs in Chinese patients with type 2 diabetes. Clin Pharmacol Ther 2011;89:437-42. http://dx.doi. org/10.1038/clpt.2010.351.

122. Huang $Q$, Yin JY, Dai XP, Wu J, Chen $X$, Deng CS, et al. Association analysis of SLC30A8 rs 13266634 and rs 16889462 polymorphisms with type 2 diabetes mellitus and repaglinide response in Chinese patients. Eur J Clin Pharmacol 2010;66:1207-15. http://dx.doi.org/10.1007/s00228-0100882-6.
123. Yu $M, X u X J$, Yin JY, Wu J, Chen X, Gong ZC, et al. KCNJ11 Lys23Glu and TCF7L2 rs290487(C/T) polymorphisms affect therapeutic efficacy of repaglinide in Chinese patients with type 2 diabetes. Clin Pharmacol Ther 2010;87:330-5. http://dx.doi.org/10.1038/clpt.2009.242.

124. Sheng FF, Dai XP, Qu J, Lei GH, Lu HB, Wu J, et al. NAMPT -3186C/T polymorphism affects repaglinide response in Chinese patients with Type 2 diabetes mellitus. Clin Exp Pharmacol Physiol 2011;38:550-4. http://dx.doi. org/10.1111/j.1440-1681.2011.05548.x. 